\title{
EVALUATION OF THE LEGAL FRAMEWORK FOR PROMOTING SUSTAINABLE DEVELOPMENT IN THE EXTRACTIVE HOST COMMUNITIES IN NIGERIA
}

\author{
Bethel Uzoma Ihugba* \\ Sergius Nnamdi Okoro**
}

\begin{abstract}
The extraction of oil and mineral wealth has some environmental, social, economic and political impact on the host communities. In many instances these communities do not derive any sustainable developmental benefit from the wealth extraction activities in their area and where they do, it is less than the magnitude of harm suffered. This has contributed to conflicts between government and host communities, and between host communities and mining companies. This suggests that either there is no legal framework for extractive industry host community development or they are weak or not applied. In Nigeria, existing legal framework includes revenue allocation formulas between the Federal and State Governments, the establishment of bodies like the Niger Delta Development Commission, and enactment of laws like the Nigeria Minerals and Mining Act (NMMA) 2007, the Nigeria Extractive Industry Transparency Initiative (NEITI) Act 2007 and the proposal of the Petroleum Industry Bill 2012 and the recently passed Petroleum Industry Governance Bill 2016. However, despite this framework, contentions persist and there is sparse evidence of sustainable development in host communities to counter some conclusions of ineffectiveness. This article, therefore, examines some of the legal framework to determine their contribution or otherwise and potential towards sustainable host community development.
\end{abstract}

Key Words: Extractive industry, local host community development, Nigeria, petroleum industry, sustainability.

DOI: https://dx.doi.org/10.4314/jsdlp.v8i1.15

* LLB, LLM, PhD, BL, Research Fellow, National Institute for Legislative Studies, National Assembly, Abuja, Nigeria. Correspondence email: bethelihugba @yahoo.com

$* *$ LLB, LLM, BL, Research Officer, National Institute for Legislative Studies, National Assembly, Abuja, Nigeria. 


\section{INTRODUCTION}

The extractive industry, particularly the oil and gas industry, has been the mainstay of the Nigerian economy for over 40 years. The revenue and the effects the exploitation of the resources from this sector has had on the local communities have led to several conflicts among communities, as well as between governments and communities, and communities and companies. ${ }^{1}$ More importantly, the benefits from the sector are yet to be properly applied to the sustainable development of the country, particularly the host communities who bear the brunt of the exploitation of the resources. ${ }^{2}$ The result has been persistent agitations by the host communities and their sympathizers across the world for the government and the extractive industry to give greater attention to the sustainable development of their communities and save the inhabitants from the deleterious effects of extractive resource development.

This article examines the legal framework for the exploitation of the resources to determine its contribution, potential or otherwise, in the application of revenue and other benefits from the extractive industry towards the development of the local community. Specifically, the article attempts to answer the question: How efficient is the legal framework for sustainable local community development in the extractive industry in Nigeria? For the purpose of clarity, unless otherwise implied, local community, is used here to mean the local population and the total

1 See Emuedo Crosdel, O. and Emuedo Okeoghene, A. "Oil Activities, Unsustainable Environment and the Combative Reactionism of Women in the Niger Delta", (2014), African Journal of Political Science and International Relations, Vol. 8(1): pp. 1-9, p. 3. DOI: 10.5897/AJPSIR12.031 < http://www.academicjournals. org/journal/AJPSIR/article-full-text-pdf/904FDF043714> accessed 9 May 2016; Ojakorotu, Victor., "Contending Issues in the Niger Delta Crisis of Nigeria" in Victor Ojakorotu (eds.), Conflict and Development Series (JAPSS Press, Inc. Bangkok, 2009) at p. 2; Ihugba Bethel U., "Compulsory Regulation of CSR: A Case Study of Nigeria" (2012), Journal of Politics and Law, Vol. 5, No. 2, p. 71; <http://www. ccsenet.org/journal/index.php/jpl/article/view/15639/ 11623 > accessed 5 December 2015; Eweje Gabriel, “The Role of MNE's in Community Development Initiatives in Developing Countries: CSR at Work in Nigeria and South Africa" (2006), Business and Society, 45(2), 93-129, at p. 113.

2 Lugard, S. Bontur, "Stakeholder Approach to Corporate Social Responsibility: Recipe for Sustainable Peace in the Niger Delta Region?" (2014), Journal of Sustainable Development Law and Policy, Vol. 4 Iss. 1, p. 155. 
environment of the place where the extractive activity is taking place. ${ }^{3}$

The rest of the article is structured as follows: subsequent to the introduction is a brief review to demonstrate the need for robust research on how to achieve sustainable development of the local community through provisions in the legal framework governing the extractive industry in Nigeria. The third section contains a detailed analysis and review of some existing and proposed regulatory framework governing the extractive industry and host community development in Nigeria. Based on this analysis, the fourth section proposes approaches for consolidation of the positive aspects of the laws and resolution of identified shortcomings. The fifth section concludes the article.

\section{THE EXTRACTIVE INDUSTRY AND SUSTAINABLE COMIMUNITY DEVELOPMENT}

The relevance of the extractive industry to host community development is a topic of much scholarly research. ${ }^{4}$ Most have viewed sustainable development in the extractive sector host communities as an aspect of corporate social responsibility (CSR) obligations of the extractive industry. ${ }^{5}$ They argue that government and the extractive industry,

3 See Nwapi Chilenye, "Defining the "Local" in Local Content Requirements in the Oil and Gas and Mining Sectors in Developing Countries" (2015), Law and Development Review 8(1): 187-216, DOI < https://doi.org/10.1515/ldr-20150008 > accessed 12 January 2016, for justification for this definition of "local community" in relation to extractive industries. He posits that "local" in local content development laws should mean the immediate communities where the extractive activities take place. The definition above, although not provided by Nwapi Chilenye (2015), is a distillation and agreement with his argument on the need for promoting and prioritizing the representation of the immediate local community, what he describes as a "bottom up approach" to implementing local content requirements in the extractive sector.

4 See IIED and WBCSD, "Breaking New Ground: The report of the Mining, Minerals, and Sustainable Development Project", Earthscan Publications Ltd, London and Sterling, VA,(2002) <http://pubs.iied.org/pdfs/9084IIED.pdf> accessed 12 January 2016.

5 See Frynas, Jedrzel George, "The false developmental promise of Corporate Social Responsibility: Evidence from multinational oil companies" (2005), International Affairs 81, 3 (2005) 581-598, p. $582<$ http://dx.doi.org/ 10.1111/j.1468-2346.2005.00470.x > accessed 10 December 2015; Tuodolo O Felix., "Corporate Social Responsibility, Local Communities and TNCs in the Oil and Gas Sector of Nigeria" PhD Thesis (unpublished) (2007), University of Liverpool, UK. 
particularly the multinational oil companies, owe the host communities CSR duties in the areas of environmental protection, employment, as well as infrastructural and social development. ${ }^{6}$ The same argument is made on resource allocation, with contentions that poor sustainable development initiatives, in host communities, contribute to conflicts in mineral producing areas and other agitations over resource control. ${ }^{7}$ Creating an environment for socio-economic development and, hopefully, reduce the ground for these conflicts and agitations is the anticipated benefits for which laws like the Nigeria Extractive Industries Transparency Initiative Act (NEITI) ${ }^{8}$ and the Nigeria Minerals and Mining Act (NMMA) ${ }^{9}$ were enacted while the Petroleum Industry Bill 2012 and the Petroleum Industry Governance Bill 2016 were proposed.

There is, however, a dearth of research on the efficiency of extant legal framework for ensuring sustainable development of the host communities. Most have been socio-political treatises on resource control and its impact on host communities, especially with reference to the oil industry. ${ }^{10}$ However, a recent research has attempted to address this question, albeit, restricted to the definition of local ${ }^{11}$ in the local content requirements in Nigeria extractive industry legislation. The article recommends a definition as host communities of extractive industries for the purpose of developmental incentives. ${ }^{12}$ Aside this

6 See Eweje Gabriel, “The Role of MNE's in Community Development Initiatives in Developing countries: CSR at work in Nigeria and South Africa" (2006), Business and Society (June) 45(2), 93-129, 113.

7 Nwankwo, Beloveth Odochi. "The Politics of Conflict over Oil in the Niger Delta Region of Nigeria: A Review of the Corporate Social Responsibility Strategies of the Oil Companies" (2015), American Journal of Educational Research, 3.4 383-392, p. 384. <http://pubs.sciepub.com/education/3/4/1/\#> accessed 10 November 2015.

8 See Section 2(e) of the NEITI Act and the EITI Principles at < https://eiti.org/ eiti/principles $>$ accessed 10 November 2015 read together.

9 Section 1(1) NMM Act 2007.

10 Adangor Zacchaeus, "The Petroleum Industry Bill 2012 and the Niger Delta Region of Nigeria: Panacea or Placebo?" (2015), Journal of Law, Policy and Globalization (Online) Vol. $38<$ http://www.iiste.org/Journals/index.php/ JLPG/article/view/23515> accessed 20 January 2015.

11 See Nwapi Chilenye, (2015) n 3.

12 This definition is similar to the one in the Petroleum Industry Bill which refers to host communities as "communities within the petroleum producing areas". This definition is still not exact; however for purposes of this paper we will adopt this definition. 
input, there is no critical examination of laws promoting local community development of host communities in Nigeria and this article addresses this gap.

The discussion here situates within the context of sustainable development. Sustainable development is a concept of how to meet essential human needs. It is "development that meets the needs of the present without compromising the ability of future generations to meet their own needs." ${ }^{13}$ This definition highlights three important functions of sustainable development policies and laws, i.e. ensuring that existing resources meet the present needs of the society, exercising control over consumption of resources and sustaining the growth of existing resources. As such, policies and laws that promote sustainable development should cover the areas of environmental, financial and human resources, including its management and governance strategies (which encompass culture and its various subsets). ${ }^{14}$ The Nigeria extractive industry legal framework covers these four areas since it regulates the exploitation of petroleum and solid minerals, which affect the environment, finance and human wealth and development of the country.

This is evident in the various sustainable development policies enshrined in the regulatory framework for the extractive industry in Nigeria. The NMMA, ${ }^{15}$ for example, provides for control, protection and reservation of certain areas from exploitation. ${ }^{16}$ It prohibits exploration or exploitation of minerals without authority. ${ }^{17}$ This is to ensure that extraction of solid minerals help grow the economy, create jobs and generate enduring wealth for the people of Nigeria, but managed so that future generations can harness the same natural resources. These objectives are emphasized under the Act in the functions of the Minister(s) responsible for the extractive industry. ${ }^{18}$

13 The Brundtland Commission report: Our Common Future (Oxford: Oxford University Press, 1987), paragraph 49 at p. 39. < http://www.un-documents. net/our-common-future.pdf $>$ accessed 12 January 2016.

14 IIED and WBCSD, "Breaking New Ground: The report of the Mining, Minerals, and Sustainable Development Project", Earthscan Publications Ltd, London and Sterling, VA, p. xvi. (2002). <http://pubs.iied.org/pdfs/9084IIED.pdf?> accessed 12 January 2016.

15 See the provisions of the NMMA 2007.

16 See for instance sections 2, 3(1)(c), 4, 17, 18 and 21 of the NMMA 2007.

17 Section 2.

18 Section 4 of NMMA 2007. 
The Minister(s) ensures the orderly and sustainable development of Nigeria's minerals resources by taking into account cultural, ecological and environmental factors when developing programmes for the exploitation of solid minerals in Nigeria. This requires that local communities participate in developing and implementing such programmes. $^{19}$

The need to promote sustainable development that incorporates local community concerns and input is also one of the thrusts of the NIETI Act 2007. This is demonstrated by its promotion of stakeholder engagement in the implementation of the objectives of the Act. Provisions like the creation of National Stakeholders Working Group ${ }^{20}$ are aimed at facilitating this objective. Other provisions like the monitoring of the application of revenue from the extractive industry also aim to enhance sustainable development objective. However, the mere enactment of law is not sufficient. Its provisions should make such objectives achievable, especially in relation to sustainable host community development. The laws should be coherent and strong enough to facilitate the transparent and accountable application of revenue from the extractive industry to designated and legitimate projects. The two laws and the Bills under examination were to achieve this objective.

\section{EXTRACTIVE INDUSTRY LEGAL REGIMES ON LOCAL COMMUNITY DEVELOPMENT}

\subsection{The Nigeria Minerals and Mining Act (NMMA) 2007}

The NMMA was enacted on 16 March $2007^{21}$ to create an environment for the mining business to flourish. It was seen as unacceptable for Nigeria to have an unranked status as a mining industry nation despite the huge amount of mineral deposits in Nigeria, unlike other African

19 IIED and WBCSD. 2002. p. xxvi. Online, Ihugba, B.U. and Osuji, O.K., "Corporate Citizenship and Stakeholder Engagement: Maintaining an Equitable Power Balance" (2011). Electronic Journal of Business Ethics and Organization Studies, Vol. 16, No. 2, pp.28-38 <http://ejbo.jyu.fi/archives/vol16_no2.html> accessed 5 January 2016. Also the importance of engagement is captured in NMMA section 117.

20 Sections 5 and 6 of NEITI Act 2007.

21 The Act repeals the Minerals and Mining Act, No. 34 of 1999. 
countries like Ghana, Tanzania, Mali, Burkina Faso and Zimbabwe. ${ }^{22}$ The NMMA was enacted, therefore, to regulate the exploration and exploitation of solid minerals in Nigeria and facilitate their contribution to sustainable national development. ${ }^{23}$

The NMMA, contains specific provisions and strategies that would facilitate the achievement of the above objective. These include the following:

\subsubsection{Environmental Protection and Social Obligation}

Mining lease holders are required to comply with environmental protection requirements and social obligations prescribed in the regulations; and to compensate owners or lawful occupiers of land for the revocation of their rights to use the land under the Act. ${ }^{24}$ This ensures that occupiers of land can use the money to engage in other gainful enterprise that would contribute to their communal and individual development.

\subsubsection{Compensation and Community Development Agreement}

There is a requirement for due compensation to occupiers of land and completion of a community development agreement (between host communities and holders of mining leases or licences), approved by the Mines Environmental Compliance Department before development work or extraction of mineral resources on the mining lease area can commence. ${ }^{25}$ This is to ensure the transfer of social and economic benefits to host communities. According to the Act, contents of the agreement may include:

i. Educational scholarship, apprenticeship, technical training and employment opportunities for indigenes of the community;

ii. Financial or material support for infrastructural development and maintenance such as education, health or other community services, roads, water and power;

22 Adeniyi Olatunbosun et al, "Legal Regime for Exploring Solid Minerals for Economic Growth in Nigeria" (2013), Journal of Canadian Social Science, Vol. 9, No. 5, 2013, p. 68.

23 Adeniyi Olatunbosun et al (2013) n.22 at p. 70.

24 Section 70 MMA 2007.

25 Sections 71, 116 and 117 MMA 2007. 
iii. Assistance with creation, development and support to smallscale and micro enterprises,

iv. Agricultural products marketing; and

v. Methods and procedures of environment and socio-economic management and local government enhancement. ${ }^{26}$

\subsubsection{Extension Services}

The Act establishes extension services for duly registered and performing mining co-operatives of small scale and artisanal miners. ${ }^{27}$ This provision has the potential of creating sustainable job opportunities within the mining sub-sector. It is a great incentive for persons interested in mining ventures and supports existing enterprises to grow. ${ }^{28}$

\subsubsection{Economic Incentives and Compensation}

Aside compensation for ownership or occupation of land provided under section 71 , there is also a requirement for payment of compensation to the owners of the land for any damage done to the surface of the land or any crop, economic trees or building etc., removed during mining operation. ${ }^{29}$

\subsubsection{Consultative and Enforcement Mechanism}

Provision of mechanism for community development agreement between host communities and mineral title holders. The agreement must make provisions for appropriate consultative and monitoring framework between the minerals title holder and the host community, including the means by which the host community may participate in

26 Section 116 (3) MMA 2007.

27 Section 91 MMA 2007.

28 The establishment of extension services should also take into consideration initiatives which will ensure that such enterprises do not constitute undue harm to the local communities especially in relation to environmental degradation and related harm. The companies and co-operatives (including artisans) must be encouraged and monitored to ensure that they also embark on CSR initiatives. CSR here is not limited to philanthropic activities but ensuring that their business activities do not constitute harm to the communities. More importantly, the development of artisanal enterprise is also a form of and route to sustainable host community development.

29 Sections 107 and 113. 
the planning, implementation and monitoring of activities carried out under the agreement. ${ }^{30}$ The provisions of the community development agreement are binding on the parties, and are subject to review every five years. ${ }^{31}$

\subsubsection{Environmental Degradation and Reclamation}

The Act provides for environmental obligation on the part of mineral title holders aimed at ensuring environmental sustainability of mining areas. $^{32}$ This is to avoid the environmental degradation problem created in the oil and gas industry and its consequential effects on sustainable community development, conflicts and disharmony in host communities.

The above provisions are illustrative of the NMMA's potential contribution to sustainable community development of host communities. Table 1 provides a more comprehensive list of all the sections that have direct provisions on local community development. These can be grouped into preservation of host communities, compensation for loss incurred due to extractive activities, incentives for economic activities in the extractive sector, developmental activities, and environment restorative objectives.

\subsection{The Nigeria Extractive Industry Transparency Initiative (NEITI) Act 2007}

The NEITI Act was enacted in 2007 to, among other things, ensure due process and transparency in the payments made by all extractive industry companies to the Federal Government and statutory recipients; monitor and ensure accountability in the revenue receipts of the Federal Government from extractive industries and ensure that the money received is duly applied for the sustainable development of the country. Although the Act does not mention local community development as a major objective, the adoption of the principles of the global Extractive Industry Transparency Initiative (EITI) ${ }^{33}$ in line with section 2 (d) and

30 Section 117.

31 Section 116(5) of the NMMA 2007.

32 Section 118.

33 The Extractive Industry Transparency Initiative is the global body of extractive industry countries whose major aim is to ensure that citizens of countries with extractive industry wealth benefit from these wealth and it is equitably applied to such countries sustainable development <www.eiti.org $>$ Nigeria is the pioneer member country to enact the principles and framework of EITI into law. 
(e) means that development of local community is one of the objectives of the NEITI Act.

Table 1. Summary of the NMMA provisions on Local Community Development

\begin{tabular}{|c|c|c|c|}
\hline $\mathbf{S} / \mathbf{N}$ & Objectives & Descriptions & Sections \\
\hline \multirow[t]{5}{*}{1} & Preservation & $\begin{array}{ll}\text { a. } & \text { Cultural }\end{array}$ & $3,70,97,98,99$ \\
\hline & & b. Economic & $72,73,78,97,100$ \\
\hline & & & 101,111 \\
\hline & & c. Environmental & $70,83,99,123,124$ \\
\hline & & & 126,127 \\
\hline \multirow[t]{2}{*}{2} & Compensation & a. Financial & $70,102,112,113$ \\
\hline & & b. Environmental & $107,108,125$ \\
\hline \multirow[t]{2}{*}{3} & Incentives & a. Economic & 70,91 \\
\hline & & b. Socio-cultural & $3(1)(c), 98$ \\
\hline \multirow[t]{2}{*}{4} & Developmental & a. Economic & $70,116,117,118$ \\
\hline & & b. Infrastructural/social & 116,119 \\
\hline \multirow[t]{2}{*}{5} & Restoration & a. Financial/Economic & $114,115,119,121$ \\
\hline & & b. Environmental & $124,128,130$ \\
\hline
\end{tabular}

Source: Authors' summary of provisions of the NMMA 2007 on Local Community Development.

According to section 2 (d) and (e), the primary objectives of NEITI are:

(d) To ensure transparency and accountability by government in the application of resources from payments received from extractive industry companies; and

(e) To ensure conformity with the principles of Extractive Industries Transparency Initiative.

Section 2 (d) includes development of extractive industry host communities because the Act mandates NEITI to monitor the application of revenue received from the extractive industries. Since such revenue form a huge part of the country's revenue base and budgetary income, it means that NEITI has the power to monitor the application of revenue under the minimum 13 per cent derivative formula provided for under section 162 of the Constitution of the Federal 
Republic of Nigeria and under the Niger Delta Development Commission (NDDC) Act 2007. This accords with the global Extractive Industries Transparency Initiative (EITI) principles that enjoin member states to promote transparency and accountability in the use of extractive industry revenue for national development; public understanding of government revenue; transparency by governments and companies in order to enhance public financial management, accountability; and informed stakeholder participation. ${ }^{34}$

Although the Act aims at promoting the use of extractive industry revenue for sustainable development, its coverage of host community development is not clear and requires better understanding and possible amendments to improve clarity. An analysis of this coverage is provided in paragraphs 4.2 below.

\subsection{The Petroleum Industry Bill 2012}

The PIB was proposed as a consolidation of the legal framework for the management of Nigerian petroleum resources. Four out of the 11 objectives of the Bill appear to be relevant to the development of oilproducing communities. These are to:

a. Enhance exploration and exploitation of petroleum resources in Nigeria and for the benefit of the Nigerian people;

b. Promote transparency and openness in the administration of petroleum resources of Nigeria;

c. Promote the development of Nigerian content in the petroleum industry; and

d. Protect health, safety and environment in the course of petroleum operations.

Although these objectives may not be achievable in isolation of the other seven, this article speaks to clauses that are relevant to the promotion of the identified four objectives as they relate to host community development. These include Clauses 8, 116 to 118 , and 296. Clause 8 empowers the Minister to make regulation for giving effect to the provisions of the Bill. Such regulation should govern the conduct of public inquiry to bring into effect the provisions of the Bill as stated in Clauses 116 (Establishment of the Petroleum Host

34 EITI principles < https://eiti.org/eiti/principles> accessed 10 November 2015. 
Community Fund), 117 (Purpose of the Fund), 118 (Beneficial Entitlements to the Communities) and 296 (Compensation to land owners).

These clauses had the potentials of making positive and sustainable impact in host communities. The feasibility of achieving these objectives is however doubtful due to some observed lapses. We analyse this potentials (including the new proposals in the latest Petroleum Industry Governance Bill 2016) later in paragraph 5.2 (1).

\section{PROVISIONS ON THE SUSTAINABLE DEVELOPMENT OF EXTRACTIVE INDUSTRY HOST COMIMUNITIES}

\subsection{The Nigeria Minerals and Mining Act (NMMA) 2007}

The NMMA has a good number of provisions that should ordinarily aid sustainable host community development. The provisions on financial compensation, incentives to economic enterprise in the mining subsector, social development, infrastructural development and environmental protection appear quite exhaustive. Its limitation, however, lies on how these objectives can be achieved when the industry is almost non-existent and limited to extraction of solid minerals while the remaining statutory mining corporations appear to exist as channels for the mismanagement of national revenue. ${ }^{35}$

The NMMA appears to have created an opportunity for this poor state of the industry because it lacks provisions for collaboration between a statutory Nigeria solid mineral company and private local or foreign companies as is done within the oil and gas subsector. For instance, section 91 that created the extension services would have been more effective if there were corresponding provisions or statutes requiring or encouraging established or multinational companies to work or collaborate with local small-scale mining companies. Without such infrastructure, the provisions on extension services remain mere aspirations without any possibility of coming to fruition.

35 Fidelis Mac-Leva, "Nigeria: Multi-Billion Contract Fraud Rocks Itakpe Iron Ore Mining Company" (2015), Daily Trust Online, 23rd August $2015<$ http:// allafrica.com/stories/201508241984.html> accessed 31 December 2015. 
The same applies to provisions on community development agreement and incentives. The provisions demonstrate positive intention for national development and environmental protection. However, the imposition of the same duties on small-scale miners without exemption may discourage potential small-scale mining investments, thereby defeating the ultimate objective of local community development initiative. ${ }^{36}$ This is because small-scale companies, generally, do not have the capacity to fulfil the terms and conditions envisaged by section 116 . Such terms and conditions are more feasible when undertaken in collaboration with big companies and government companies. In other words, despite the apparent host community development provisions of section 116 of the NMMA 2007, their sustainability is in doubt.

\subsection{Nigeria Extractive Industry Transparency Initiative (NEITI) Act 2007}

The NEITI Act has the key objective of ensuring sustainable development of the country through transparency and accountability frameworks. The viability and coherence of the Act with this objective is comprehensively discussed in other works. ${ }^{37}$ What is relevant here is how the Act promotes sustainable development of local communities in Nigeria. A cursory analysis of the Act shows that it does not emphasize oil producing communities. It rather relates generally to the sustainable development of the entire country.

However, section 2(a), (d) and (e), of the NEITI Act could be decoupled to mean the development of local (extractive industry host) communities, especially when section 2 is read in conjunction with Section 14 (2) (c) of the NDDC Act 2000. According to section 2(a), (d) and (e) of the NEITI Act, NEITI's primary objectives are to:

36 The provision should, either by regulation or statutorily, clearly classify the companies and stipulate what level of community development projects that would be expected of them. This will ensure that small scale miners are encumbered with oversize community development projects.

37 Ihugba Bethel U., "Compulsory regulation of CSR: A case study of Nigeria" (2012), Journal of Politics and Law, Vol. 5, Issue 2 <DOI: 10.5539/jpl.v5n2p68> Ihugba, Bethel U. "A critical analysis of the auditing and reporting functions of Nigeria Extractive Industry Transparency Initiative (NEITI) Act 2007: Lessons for EITI countries" (2014), Journal of International Trade Law and Policy, Vol. 13 , Issue 3 , pp. 232-245. 
(a) Ensure due process and transparency in the payments made by all extractive industry companies to the Federal Government and Statutory Recipients.

(d) Ensure transparency and accountability by government in the application of resources ${ }^{38}$ from payments received from extractive industry companies; and

(e) To ensure conformity with the principles of Extractive Industries Transparency Initiative. ${ }^{39}$

The above provision are to be read along with Section 14 (1) and (2) (b) (c) of the NDDC Act 2000, which empowers the NDDC to establish and maintain a fund from which shall be defrayed all expenditure incurred by the Commission, and identifies sources of such funds. The NDDC, amongst other things, is specifically mandated to use this fund for the development of oil producing areas. ${ }^{40}$

\section{ANALYSIS OF THE SUSTAINABLE LOCAL (EXTRACTIVE INDUSTRY) COMIMUNITY DEVELOPIENT PROVISIONS OF NEITI, NMMA AND PIB(S)}

\subsection{NEITI 2007}

To illustrate the relationship and potential of NEITI provisions to sustainable host community development, the relevant sections are analysed below.

A. Due process and transparency in the payments made by all extractive industry companies to the Federal Government and Statutory Recipients.

This provision means that for purposes of ensuring transparency and accountability, NEITI is empowered to monitor all money transmitted from the extractive industry companies and paid to the Federal Government and all

38 Put in italics for emphasis. See paragraph 5.1 (a), (b) and (c) below for analysis.

39 Section 2 NEITI Act 2007.

40 Section 7 NNDC Act 2000. 
statutory recipients. ${ }^{41}$ So the key criteria for invoking NEITI's jurisdiction are:

a. Is the money being paid by an extractive industry company? and

b. Is the recipient the Federal Government? or

c. Is the recipient empowered to receive any money from the extractive industry by any federal statute?

An affirmative answer to all of these questions or to (a) and either of (b) or (c), means that NEITI can assume responsibility for ensuring due process and transparency in the transmission of the money in question. This interpretation is supported by the provision of clause 4 of the Petroleum Industry Bill 2012. Clause 4 of the Bill requires all agencies and companies established under the PIB to be bound by the provisions of the NEITI Act 2007. In other words, the argument for transparency as a promoter of local community development in the extractive industry is logically and factually justified. The next issue here in relation to NEITI Act, is to examine the significance of the requirement of monitoring the application of the money so received. ${ }^{42}$

B. The application of revenue from payments received from extractive industry companies.

Under this provision NEITI has a duty to ensure that all monies paid by the extractive industry companies to government and statutory recipients are duly applied to the purposes for which they were meant. Such purposes need not be defined by the NEITI Act but may be defined by the Act requiring the payment from the extractive industry

41 The Act is not explicit as to whether NEITI's jurisdiction extend to State and Local Governments. However, a reading of section 2, which for purposes of context, provides for the objectives of the Act suggests that this is the case. The other interpretation may be that the Act applies to either State or Federal Government depending on the activity in question. That is, the Federal Government is covered when the activity is receipt from the extractive industry companies (see section $2 \mathrm{a}, \mathrm{b}$ and c). But when it relates to use of monies received from the extractive industry through the Federal Government, State and Local Governments are included. See section 2 (a); 3 (c), (e) and (g).

42 Section 2 (d) and (e) of NEITI Act 2007. 
company, ${ }^{43}$ e.g., the NDDC Act. In other words, NEITI is required to ensure transparency and accountability in such cases, and has the power to monitor the application of monies received from the extractive industry under Section 14 (1) and (2) (c) of the NDDC Act for host community development. The section stipulates thus:

(1) The Commission shall establish and maintain a fund from which shall be defrayed all expenditure incurred by the Commission.

(2) There shall be paid and credited to the fund established pursuant to subsection (1) of this section-

(c) 0.5 per cent of the total annual budget of any oil producing company operating, on shore, in the Niger Delta area.

By the above provision, NEITI has the power to monitor transparency and accountability of the disbursement of the money to the NDDC and application of that money by the NDDC in accordance with the NDDC Act. The NDDC Act defines the areas the money can be applied to as the development of the communities hosting the oil and gas companies. ${ }^{44}$ Therefore, it is correct to state that the NEITI Act ensures transparency and accountability in the sustainable development of extractive industry host communities.

C. Ensuring conformity with the principles of Extractive Industries Transparency Initiative.

The NEITI Act requires conformity to the principles of the global EITI. ${ }^{45}$ The twelve principles of the EITI mandate member countries to abide by stipulated transparency and accountability standards in fulfilling sustainable development objectives. The requirements include the general procedure for the fulfilment of the sustainable development initiative. The twelfth principle encourages stakeholder engagement. This means that local communities should be engaged in developing

43 Section 2 (a) of NEITI Act 2007.

44 See section 7 NDDC Act 2000, in this case the Niger Delta States as defined by the Act.

45 Section 2 (1) of the NEITI Act 2007. 
and implementing development programmes and projects in their communities. The twelfth principle states that:

In seeking solutions, we believe that all stakeholders have important and relevant contributions to make - including governments and their agencies, extractive industry companies, service companies, multilateral organizations, financial organizations, investors, and non-governmental organizations.

Although, local communities are not mentioned in the above quote, it could be inferred that since they are affected by business activities of the industry, they are stakeholders and therefore are contemplated by the Act. The absence of specific mention of communities as stakeholders, however, demonstrates lack of clarity in the provisions and thus requires resolution. It must be recognized, however, that NEITI (as a body, and not the Act), does conduct stakeholder engagement and sensitization programmes with the local communities. Also the publication of NEITI audit is a means of engaging the public. Thus, although engaging with local communities is necessary, one could argue that it does not need to be specifically stipulated in the Act but would rather arise from stipulated objective of any engagement exercise. ${ }^{46}$

\section{2 (1) Proposed Petroleum Industry Laws 2012 and 2016}

The proposed law for the Petroleum Industry has undergone several transformations. In the course of these transformations two versions of the Bill have emerged. First is the Petroleum Industry Bill 2012, which appears to have been abandoned, and the current Petroleum Industry Governance Bill 2016. For the purpose of this article, relevant

46 This requirement should not be confused with the activity or function of the NSWG under the NEITI Act 2007. Why the term stakeholder is used, they do not specifically represent host communities. But through direct engagement with host communities, NEITI as a body could monitor the application of revenue ear marked for the development of host communities. It is in this sense that we use the term stakeholder engagement and not on the same definition with NEITI's NSWG. 
clauses of both Bills are discussed below to underscore their potential or otherwise to sustainable local community development.

\subsection{Petroleum Industry Bill 2012}

First is the Petroleum Industry Bill 2012, ${ }^{47}$ which made significant provisions on host community development, specifically clauses 116 to118 and 296. However, the wordings of the provisions expose its implementation to inefficiency, as shown below.

\subsubsection{Ambiguity on Petroleum Host Community Fund (PHCF)}

The provision on community engagement (conducting public inquiry), which is left at the discretion of the Minister, exposes the law to inefficiency in relation to disbursement of the PHCF. This is because although Clause 118 (6) mandates the Minister to abide by regulations on consultation with communities, it appears that this mandate is watered down with the wide discretion given to Ministers to conduct public enquiry. ${ }^{48}$

Clause 8(5) provides that the Minister may make regulations without engaging the communities "due to the exigency of the circumstances". ${ }^{49}$ This defeats the aim of the provision. The intent of clause 8 (amongst others) is to carry along the communities and to ensure that whatever project or sharing method applied is relevant to needs of the communities as may be determined through public enquiry. When, however, the minister carries out this activity without involving the communities, stakeholder engagement benefits are lost.

\subsubsection{Compensation for Disturbance of Land Surface}

Petroleum exploration and prospecting licence and mining lease holders are required to pay compensation to owners or lawful occupants of land for the disturbance of the surface of the land arising from the activities of extractive industry companies. ${ }^{50}$ This ensures that land owners do not suffer undue loss. The payments enable the owners or

47 The PIB 2012 is still relevant because indications from the National Assembly suggest that the provisions on local host community development will be reintroduced as an independent Bill in 2017.

48 Clause 8(5) PIB 2012.

49 The Bill however fails to define what may amount to "exigency".

50 Clause 296 of the PIB. 
lawful occupants of disturbed land to recoup a similar level of benefit from the land had it not been affected by extraction activities.

\subsection{Petroleum Industry Governance Bill 2016}

The Petroleum Industry Governance Bill 2016 is a departure from the 2012 Bill in terms of local community development. The provisions of the 2012 Bill on Local Community Development are now absent. ${ }^{51}$ However, the Bill in its clauses 2, 5, and 7 allude to local community development. This provisions are not clear and require proper clarification if the intent is to improve sustainable development of local communities.

For instance, Clause 2 of the Bill empowers the Minister to "promote the development of local content in the development of the Nigerian petroleum industry". If the term "local" used in this Bill is interpreted as suggested in this article, ${ }^{52}$ this could mean the application of the Nigeria Oil and Gas Industry Content Development Act (NCAD) 2010, with necessary adaptation, to the development of oil producing communities. This interpretation is possible as, according to clauses 5(h) and 7(g), the Minister and Commission are required to strictly enforce all laws relating to the oil and gas industry that are in existence at the commencement of the Bill. The NCAT, NNDC, NEITI are to be strictly enforced by this provision..$^{53}$ In other words, although the 2016 Bill removed Host Community development provisions of the 2012 Bill, a similar objective could be achieved with proper application.

\subsection{Leveraging Community Development Provisions of the Extractive Industry Legal Framework (NEITI, NMMA and PIB)}

As demonstrated in the paragraphs above, the legal framework for sustainable host community development still require some improve-

51 There are talks in the Senate of a Petroleum Industry Host Community Management Bill, supposedly proposed for January 2017. However, discussion in this article is limited to the current Bill and on the premise that there is only one Bill.

52 See Note 3 above and Nwapi Chilenye (2015).

53 In line with the above interpretation, all the analysis herein on NEITI and NNDC will apply. The NCAT, NNDC, and NEITI following the analysis in this article could be leveraged to ensure sustainable local community development of oil producing communities. 
ment to fully exploit its potentials. The procedure and feasibility of ensuring host/local community development require clarification and strengthening in order to secure their success as tools for achieving sustainable local community development. Some of the specific provisions suggested for improvement and how it can be achieved are demonstrated below.

First, in relation to the NEITI Act 2007, clarity is required on the provisions on transparency and accountability in the application of money received from the extractive industry. The provision should state clearly that NEITI has the power to audit and take record of all receipts, disbursements and application of all monies received from the extractive industry by any government, agency, ministry and department under any law. The requirement for fulfilling this function must be stated and this shall constitute the criteria for measuring successful application. The Act could be amended to confer on NEITI the power or function of establishing regulations for determining what constitutes local community and what companies, governments and agencies need to do to fulfil the requirement of application of stipulated revenue to host community development. This could include clear provisions mandating NEITI and NDDC to involve community stakeholders in the choice of projects, monitoring of the disbursement and application of the money and on the effectiveness of programmes completed with such funds.

Also since NEITI is mainly concerned with ensuring transparency and accountability, local community stakeholders should be informed of the revenue derived from the industry and allocated for the development of their communities. This will ensure that the monies are applied transparently and in accordance with the informed wishes of the local communities. ${ }^{54}$ It will also provide the National Assembly with verifiable information for conducting its oversight function in relation to application of money received from the extractive industry by the government. ${ }^{55}$

Second, in relation to the NMMA 2007, the Act should be amended

54 The definition of local community for purposes of application of the money, amongst other objectives, must also be defined by the relevant statute to enable proper implementation and monitoring of progress.

55 Section 88 and 89 of the Constitution of the Federal Republic of Nigeria as amended. 
to mandate government to fund initiatives that spur economic activities in the mining sector. This should include provision of soft loans for small-scale miners and artisans in host communities to access. Government should also set up mining business and invite partnerships from local small-scale miners and artisans. This will encourage smallscale miners and artisans to access the extension services and enable government fund the capital intensive aspect of the businesses, which will give the small-scale extractive businesses growth leverage.

Also, the provision on extension services should be vigorously implemented. Local community members who are already engaged in the mining sector should be educated and incentivized to form cooperatives in order to benefit from the extension programmes, access available soft loans and other benefits provided under the Act. The Act should be amended to mandate the extension services to carry out supply-driven proactive programmes. The wording of section 91, that is - "the Government through the Ministry shall provide the following extension services to duly registered and performing mining co-operatives of small scale and artisanal miners" 56 - is very restrictive. It means that it is only upon application of a duly registered entity that such services can be provided.

Further, this provision is reactive. It should be expanded to confer on the extension services a proactive commercial cum welfare approach to fulfilling its function. This may include the education and training of aspiring small scale miners, including provision of logistics and equipment for establishing and registering a profitable small scale mining and artisanal business. This may mean that the extension services will not have to wait for registered business to apply for its services but also to spur the establishment and flourishing of such businesses particularly in local host communities. ${ }^{57}$

Third, in relation to extractive industry sector in general, the local community development provisions should be developed to cover exploration, exploitation, and refining or production of goods using

56 Section 91 NMMA 2007.

57 The Minister could exercise the power to make regulation to provide for realistic and proactive criteria for accessing the incentives. This will help to make access easier but capable of being assessed, e.g. business plan, previous verifiable experience, training or qualifications, and any other criteria that could demonstrate capacity, commitment and sincerity. 
raw materials from the extractive sector. Local community businesses should not be limited to only extraction. The relevant laws should be amended to mandate government to fund and spur technological competence and business capacity amongst local communities and the country in general for participation in all stages and linkage sectors of the extractive industry. This will ensure the creation of opportunity for such skills and capacity to be exported to countries, developed and developing, that may need them. ${ }^{58}$

Fourth, the excessive emphasis on exploitation and exportation should be minimized and the industry diversified. Diversification here implies what may be regarded as internal diversification, as against external diversification. This is sometimes termed development of linkages. Evidence however suggests that the linkage usually referred to in the extractive industry in developing countries does not extend to the refining or manufacturing of products using minerals. Rather, it relates mainly to service providers to the extractive industry and at best the application of revenue from the extractive industry to other mainly non-productive activities that help promote the externalization of development in the sector - i.e. solid mineral and petroleum export promotion activities. These are not diversification but rather unavoidable services whose sole purpose is to enhance extraction and export activities.

Such linkages, while they may have their immediate benefits, are lacking in sustainability and do not facilitate the development of the technical knowledge and skills of the community beyond mining and mineral exploitation. In other words the legal regime of the extractive sector should be revised and amended to create initiatives and opportunities for value creation in terms of technological development not necessarily dependent on or related to the extractive sector but capable of being applied in other sectors.

Fifth, the PIB 2012 should be revised to address the problem of wide discretion given to the Minister in relation to the disbursement and application of PHCF for host community development. The PIB 2012 position of giving the Minister a wide discretion to determine payment and mode of payment may open door to corruption and limit the efficacy of the PHCF. Also there is no clear definition of Petroleum

58 This would hopefully avoid the need to depend on foreign experts when such experts could be trained here in Nigeria. 
Host Community. The Bill needs to be more explicit in defining Petroleum Host Community. The implied definition in clause 117 as "communities within the petroleum producing areas" is insufficient. It is not clear whether it refers to villages, towns, local government areas or some other demarcation. ${ }^{59}$

With regards to the 2016 Bill and without prejudice to the proposed Petroleum Industry Host Community Management Bill, ${ }^{60}$ the content of the Petroleum Industry Governance Bill, while not sufficient to fulfil host community development initiatives, could be amended to achieve a similar aim. This will include redrafting clauses $5(\mathrm{~h})$ and $7(\mathrm{~g})$ to specifically reference NCAT, NNDC, NMMA and NEITI as laws that are to be strictly enforced by the Minister and Commission.

Finally, there must be provisions for productive and sustainable community engagement, transparency and accountability framework. Community engagement is necessary from initiation to completion of projects to ensure that initiatives address the concern and interests of communities. ${ }^{61}$ Also community will benefit both on capacity building during the project and from the final products of the project. It is an opportunity for the community to take ownership of programmes instead of imposed projects that may have no relevance to their circumstance. It is also the opportunity to use available local resources within a community. That way, the communities would make optimum use of available resources, both human and natural, in building their future. The legal framework must ensure that agreements are strictly adhered to and their performance monitored and enforced. ${ }^{62}$

59 Especially, when you consider that although oil exploration may be taking place in one community, its effect like water pollution, gas flaring and acid rain, may be affecting neighbouring communities without oil wells or in which no exploration activity is taking place.

60 References were made to a Host Community Management Bill at the public Hearing on Petroleum Industry Governance Bill 2016.

61 See Sections 116 and 117 attempts to achieve these objectives. There is however need for this approach to be applied in other extractive industry subsectors. Also see Ihugba Bethel and Osuji Onyeka, "Corporate Citizenship and Stakeholder Engagement: Maintaining an Equitable Power Balance",(2011) Electronic Journal of Business Ethics and Organization Studies, Vol. 16, No. 2, p. 33. < http://ejbo.jyu.fi/pdf/ejbo_vol16_no2_pages_28-38.pdf> accessed 7 January 2016, for what constitutes sustainable stakeholder engagement.

62 See section 117 NMMA 2007. 


\section{CONCLUSION}

Sustainable local community development is beneficial to profitability of the extractive industry and should be an important goal in the exploitation of extractive resources in Nigeria. It is a catalyst to sustainable development of the extractive sector as it ensures harmony within the affected communities and political legitimacy of government decisions affecting the industry. Sustainable local community development enriches the country and the extractive industry with human resources (e.g. locally sourced skilled experts) and infrastructure (e.g. good communication network, hospitals and schools), that makes doing business sustainably profitable.

It is also a key approach to development that rightly reflects the promotion of fundamental human rights. As demonstrated in this article, this is most feasible within an inclusive and enforceable legal framework. It must be recognized, however, that amending the existing laws may be vigorously opposed by certain interests; hence the need for stakeholder engagement (of communities, the extractive industry, government and other relevant stakeholders). This will ensure that the recommendations go through a transparent, accountable and informed law making process that is refined and inclusive of concerns of all stakeholders. The Nigerian government must, however, realize that its first duty is the well-being of citizens of Nigeria before any commercial interests. The government should ensure that laws are fully developed to enhance community participation in the extractive industry and that generated and allocated revenues are properly applied to the designated host community development projects and programmes. As evidenced above, the legal machineries are already available; all that is required is fine tuning and proper implementation. 